\title{
KONTAKTNI KRAS V KOČEVSKEM ROGU IN KOČEVSKI MALI GORI
}

Petra Gostinčar, univ. dipl. geogr.

Inštitut za raziskovanje krasa ZRC SAZU, Titov trg 2, SI-6230 Postojna

e-mail: petra.gostincar@zrc-sazu.si

Izvirni znanstveni članek

COBISS 1.01

\section{Izvleček}

$\mathrm{Na}$ dinarskih kraških planotah Kočevskega Roga in Kočevske Male gore se je na kontaktu med kraškim in fluvialnim geomorfnim sistemom oblikoval t.i. kontaktni kras. Preučene so bile geomorfološke oblike in procesi na štirih območjih kontaktnega krasa. $\mathrm{Na}$ stiku med nekarbonatnimi in karbonatnimi kamninami so se razvile ponikve, slepe doline (aktivne in fosilne), konkavne oblike v bližini kontakta pa so zapolnjene z nekarbonatnimi sedimenti. Na kontaktu med različnimi karbonatnimi kamninami (dolomiti in apnenci) so reliefne oblike kontaktnega krasa manj jasno izoblikovane, mdr. ponori (aktivni in fosilni), ponorni zatrepi ter suhe doline.

Ključne besede: Kočevski Rog, Kočevska Mala gora, geomorfologija, kras, kontaktni kras

\section{CONTACT KARST OF KOČEVSKI ROG AND KOČEVSKA MALA GORA}

\begin{abstract}
On high Dinaric karst plateaus of Kočevski Rog and Kočevska Mala gora, the so-called contact karst is present. Geomorphic processes and landforms of four case study areas of contact karst were researched in detail. Two types of contact karst were recognized: between non-carbonate and carbonate rocks and between different carbonate rocks. In the first case, ponors and blind valleys (active and fossil) were formed and concave forms near the contact are infilled with non-carbonate sediments. On the contact between different carbonate rocks (dolomite and limestone), the forms are similar but less evident, e.g. ponors (active and fossil), ponor steepheads and dry valleys.
\end{abstract}

Key words: Kočevski Rog, Kočevska Mala gora, geomorphology, karst, contact karst 


\section{UVOD}

Sklenjeno območje visokih dinarskih kraških planot Kočevskega Roga in Kočevske Male gore leži v jugovzhodni Sloveniji. Za to območje je z geomorfološkega vidika značilna predvsem prevlada kraških geomorfnih procesov in s tem tudi razširjenost podzemnih in površinskih kraških pojavov, ki pa v preteklosti zaradi odmaknjene lege niso bili podrobneje preučeni. Za visoke kraške planote je značilen pretočni tip krasa, kar pomeni, da se vode pod njimi pretakajo podzemeljsko, na površju pa je fluvialni relief redko prisoten. Kljub temu da na območju Kočevskega Roga in Kočevske Male gore prevladuje kraški relief, se na manjših območjih pojavlja nekraški, oziroma fluvialni ter fluviokraški relief (Gostinčar, 2009), ki na kontaktu s kraškim tvori kontaktni kras, za katerega so značilne specifične oblike in procesi.

Namen raziskave je bila podrobna preučitev geomorfoloških značilnosti kontaktnega krasa na območju Kočevskega Roga in Kočevske Male gore, saj tovrstne raziskave na tem območju še niso bile opravljene. Članek podrobno opisuje geomorfološke značilnosti izbranih območij kontaktnega krasa. Preučena so bila štiri območja, in sicer na stiku med nekarbonatnimi in karbonatnimi kamninami med Grintovcem in Starim Bregom ter na stiku različnih karbonatnih kamnin (apnencev in dolomitov) na območju Nemške Loke, Ribnika in Svetlega Potoka.

Raziskava je obsegala podrobno geomorfološko kartiranje vzorčnih območij v merilu 1 : 5000 oziroma $1: 10.000$, na podlagi s kartiranjem pridobljenih podatkov pa so bile s pomočjo ArcGIS programske opreme izdelane podrobne geomorfološke karte. Z namenom določitve izvora sedimentov na površju in $\mathrm{v}$ jamah, ki so pomembni za razlago morfogeneze, so bili pobrani vzorci sedimentov in kasneje analizirani v laboratoriju. Vzorcem je bila določena kamninska sestava, in sicer smo jih najprej prelili z raztopino vodikovega peroksida $\left(\mathrm{H}_{2} \mathrm{O}_{2}\right)$, ki je raztopila vezivo med posameznimi delci, nato pa je bil sediment presejan skozi sito. Kamninska sestava presejanih delcev je bila določena s pomočjo mikroskopa.

\section{ORIS PREUČEVANEGA OBMOČJA}

Območje visokih dinarskih kraških planot Kočevskega Roga in Kočevske Male gore obsega približno $363 \mathrm{~km}^{2}$ veliko ozemlje, ki meji na Kočevsko polje na zahodu, Suho krajino na severu, doline Krke, Črmošnjice in Divjega potoka ter Belo krajino na vzhodu in Poljansko goro na jugu. To planotasto pogorje je v dinarski smeri (SZ-JV) dolgo 19-25 kilometrov in široko približno 18 kilometrov (Hrvatin, 1999). Najvišji vrhovi segajo prek tisoč metrov (Veliki Rog 1099 m, Kopa 1077 m, Mirna gora 1047 m), najnižji deli na stiku z dolino Krke dosegajo nadmorske višine le okoli 180 metrov. Preučevano območje sestavljajo tri reliefne enote: planotasti pogorji Kočevski Rog in Kočevska Mala gora ter vmesni pas nižjega sveta - Rajhenavsko ali Koprivniško podolje (Gostinčar, 2009).

V geološkem pogledu ozemlje Kočevskega Roga in Kočevske Male gore sestavljajo večinoma mezozojske karbonatne kamnine; zastopane so kamnine vseh treh sistemov: triasa, jure in krede. Najmanj je triasnih kamnin (predvsem zgornjetriasni dolomiti), 
ostalo so jurski in kredni apnenci ter v manjši meri dolomiti. V manjšem obsegu se pojavljajo še terciarni (eocenski flišni) in kvartarni sedimenti. Območje sekajo številni prelomi dinarske in prečnodinarske smeri, ob katerih so se posamezne grude dvignile ali pogreznile. Prisotni so tudi številni pokrovi oziroma narivi (Hrvatin, 1999).

Litološka in tektonska zgradba preučevanega območja ima velik vpliv na njegove hidrološke značilnosti. V kraškem vodonosniku se večji del vode pretaka globoko v kraškem podzemlju, površinski vodni tokovi so zelo redki. Prevladujoča smer podzemnega odtoka je zahod-vzhod (Habič, 1989). Zaradi dokaj homogene litološke sestave raziskovanega območja določajo pretok podzemne vode (pa tudi potek površinskih voda) predvsem prelomi, natančneje notranja zgradba prelomnih con (Čar, 1982; Lapanje, 2000).

Zaradi prevlade karbonatnih kamnin ima velik del površja izrazite kraške poteze. Razvite so številne kraške oblike, kot so kraške jame, vrtače, kopasti vrhovi, suhe doline, večje kraške kotanje in drugo (Gostinčar, 2009). Na geomorfne procese danes vpliva predvsem avtogeni dotok vode s padavinami - območje v povprečju letno prejme $1579 \mathrm{~mm}$ padavin (Hrvatin, 1999). V pleistocenu je bil večji del Kočevskega Roga in Kočevske Male gore v višinah med zgornjo gozdno mejo in snežno mejo (med 400 in $1300 \mathrm{~m}$ ) in pod vplivom periglacialnih geomorfnih procesov. Prevladovalo je intenzivno mehansko razpadanje zaradi zmrzali, intenzivni sta bili tudi denudacija in soliflukcija (Melik, 1955; Komac, 2006). Posebno vlogo naj bi imeli dolomiti, ki naj bi bili v hladnih dobah neprepustni in bi omogočali površinsko pretakanje vode in s tem erozijsko-akumulacijske procese (Habič, 1968).

\section{OBMOČJA KONTAKTNEGA KRASA}

Ponorni kontaktni kras je tip krasa, ki nastane tam, kjer pritekajo vode s fluvialnega reliefa na kras (Mihevc, 1991), torej na stiku vododržne in vodoprepustne kraške kamnine (Gams, 1974; 2003). V literaturi je največkrat obravnavan kot stik med nekarbonatnimi (nekraškimi) in karbonatnimi (kraškimi) kamninami. V ožjem pomenu vsebuje kontaktni kras pojave in oblike, ki se izoblikujejo zaradi stika med zakraselimi in nezakraselimi kamninami. V širšem pomenu je kontaktni kras tudi kras na stiku dveh zakraselih kamnin z različnimi značilnostmi - kemično sestavo, poroznostjo, gostoto razpok, itd. Po tej tipologiji je kontaktni kras lahko stratigrafski, tektonski ali sedimentni (Sauro, 2001). Obstaja torej tudi kontaktni kras znotraj karbonatnih kamnin, ki pa ga avtorji (Mihevc, 1991; Gams, 2003; Ford, Williams, 2007) omenjajo zgolj kot možno obliko kontaktnega krasa, z njegovim preučevanjem pa se, razen nekaterih manjših raziskav in omemb v literaturi (Habič, 1968; Radinja, 1972; Mihevc, 1979; 1991; Čar, Šebela, 2001; Zagoda, 2004; Čar, Zagoda, 2005; Gams, 2003; Mivšek, 2007), še nihče ni sistematično ukvarjal. Dolomit, ki je sicer tudi ena izmed glavnih kraških kamnin, zaradi kemičnih in mehanskih lastnosti drugače prepereva kot apnenec. Zato se na njem lahko pojavlja t.i. fluviokraško preoblikovanje, na stiku z apnenci pa se lahko oblikuje svojevrsten tip kontaktnega krasa.

Kontaktni kras na stiku nekarbonatnih in karbonatnih kamnin so v nasprotju z zgoraj omenjenim tipom na območju Slovenije obravnavali številni avtorji (npr. Šerko, 1964; Čadež, 1952; Habič, 1975; 1988; Gams, 1962; 1983; 1986; 1995; 2001; Mihevc, 1989; 1991; 1993; Hribernik, 2005, Stepišnik in sod. 2007a; 2007b; Stepišnik, 2009; 2010). 
Površinske vode s svojo količino, režimom, naplavino in kemičnimi lastnostmi modificirajo kraške procese ter oblikujejo svojstven površinski relief, katerega razvoj pa je odvisen tudi od hidravlične prevodnosti krasa, hidravličnega gradienta vtoka, načina vtoka v kras (bočni ali navpični) ter časa (Mihevc, 1991; Ford, Williams, 2007). Na kontaktnem krasu so razvite značilne reliefne oblike, v Sloveniji slepe doline, ponorni zatrepi (Mihevc, 1991), suhe doline, skupine udornic v kraškem zaledju večjih ponorov (Stepišnik, 2006) in reliktni vršaji (Stepišnik in sod., 2007b). Na stiku se pojavljajo jame $\mathrm{z}$ vodoravnimi odseki, ki nastajajo v epifreatični coni (Renault, 1967).

Ugotovljeno je bilo (Gostinčar, 2009), da se na območju Kočevskega Roga in Kočevske Male gore pojavljata dva tipa kontaktnega krasa, in sicer:

- na stiku med nekarbonatni kamninami (zgornjekrednimi in eocenskimi flišnimi sedimenti) in karbonatnimi kamninami (krednimi apnenci) ter

- na stiku med različnimi karbonatnimi kamninami - jurskimi dolomiti in apnenci.

Preučena so bila štiri območja, na katerih se pojavlja eden izmed obeh omenjenih tipov kontaktnega krasa: na stiku med nekarbonatnimi in karbonatnimi kamninami med Grintovcem in Starim Bregom ter na stiku dolomitov in apnencev na območjih Svetlega Potoka, Nemške Loke in Ribnika (slika 1).

Slika 1: Območje Kočevskega Roga in Kočevske Male gore z označenimi preučevanimi območji Figure 1: The area of Kočevski Rog and Kočevska Mala gora with case study areas

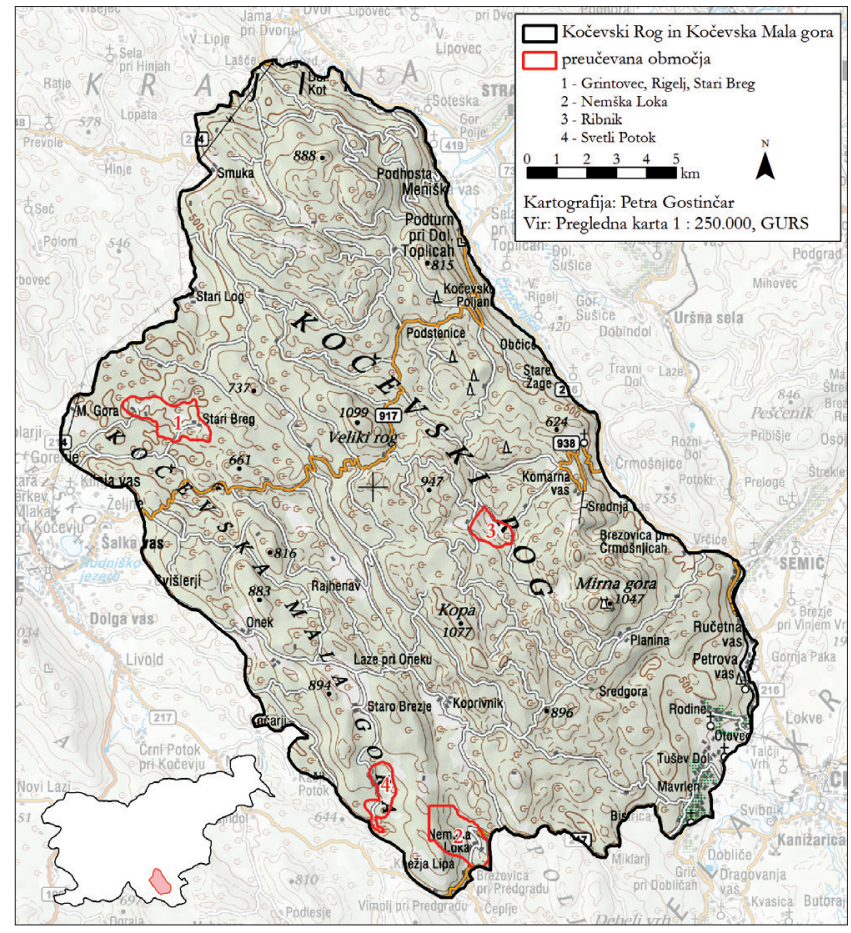




\section{I. Kontaktni kras na stiku nekarbonatnih in karbonatnih kamnin}

Območje med Grintovcem, Rigljem in Starim Bregom se nahaja na severnem delu Kočevske Male gore na nadmorski višini okoli $520 \mathrm{~m}$. Na $3 \mathrm{~km}$ dolgem in povprečno $300 \mathrm{~m}$ širokem pasu eocenskih laporovcev in peščenjakov $\left(\mathrm{E}_{1,2}\right)$, ki imajo flišni značaj, se je izoblikoval fluvialni relief. Območje je erozijski ostanek nekdaj bolj razširjenih eocenskih kamnin (Germovšek, 1953). Na obrobju eocenski sedimenti prehajajo v bele do sive rudistne apnence $\left(\mathrm{K}_{2}^{2}\right)$ (Osnovna geološka karta SFRJ, list Ribnica, 1968), na katerih poteka proces zakrasevanja. Na stiku med fluvialnim in kraškim geomorfnim sistemom se je oblikoval kontaktni kras.

Na pasu eocenskega fliša je prisotno fluvialno preoblikovanje reliefa. Na severni strani preučevanega območja, kamor se steka večina vode, zasledimo šest skupin erozijskih jarkov; vode s teh območij ponikajo ločeno. Na kontaktu z apnencem so se oblikovale 30-50 m dolge slepe doline s strmejšimi robovi. Slepa dolina vodotoka z največjim porečjem se nadaljuje s približno $250 \mathrm{~m}$ dolgo in do $95 \mathrm{~m}$ široko neaktivno, oziroma fosilno slepo dolino. Dno fosilne slepe doline je v površju vidno kot niz konkavnih oblik, zapolnjenih s sedimentom (sestavljajo ga kremenova, boksitna in limonitna zrna ter delci flišnega peščenjaka). Voda iz enega izmed erozijskih jarkov na kontaktu ponikne v vrtači. Na površju na apnencih v bližini kontakta lahko ponekod zasledimo morfološke ostanke nekdanjega površinskega toka oziroma kontaktnega krasa - gre za konkavne podolgovate reliefne oblike, ki spominjajo na erozijske jarke, le da danes po njih voda ne teče več, na dnu pa so debelejše plasti nekarbonatnih sedimentov. Trije krajši erozijski jarki se nahajajo tudi v južnem delu preučevanega območja, vode iz njih so na kontaktu $\mathrm{z}$ apnenci izoblikovale manjše slepe doline.

Vrtače, ki se nahajajo neposredno ob stiku eocenskih flišev in apnencev, so največkrat zapolnjene z debelo plastjo sedimentov. Največ sedimentov flišnega izvora lahko zasledimo na južnem pobočju pod Rigljem. Opravljena je bila petrološka analiza sedimenta v dnu dveh vrtač. V sedimentu prve vrtače, ki se nahaja na pobočju nad kontaktom, je bil najden velik delež nekarbonatnih primesi (kremen, sljude), ki kažejo na flišni izvor. V sedimentu vrtače z uravnave, ki se širi od kontakta proti severozahodu, so bili najdeni do $1,7 \mathrm{~cm}$ veliki kremenovi prodniki, prodniki kremenovega peščenjaka in laporovca ter boksitna zrna in sljuda. Domnevamo, da je uravnavo nekdaj zapolnjeval sediment s flišnih kamnin in tako lokalno vzdrževal nivo piezometra.

Na morfogenezo oziroma razvoj površja na kontaktnem krasu kažejo tudi ostanki jam, ki so se oblikovale v epifreatični coni - bodisi na območju današnjega kontakta, ali pa so od kontakta te jame danes oddaljene. Na tem območju se pojavlja ena epifreatična jama (Ostra jama, kat. št. 5111), v katero občasno ponikajo vode $\mathrm{z}$ neprepustne flišne podlage. V šestih jamah so bili najdeni sledovi nekdanjih vodnih tokov in sedimenti flišnega izvora (kremenčev pesek, prod in konglomerat), zato jih lahko označimo kot neaktivne oziroma fosilne epifreatične jame (Medvedova jama, kat. št. 5112; Jama pri Jelenovi mlaki, kat. št. 5117; Adidas jama, kat. št. 6242; Kropfova jama, kat. št. 7034; Prehodna jama, kat. št. 3326) (Kataster jam JZS, 2010). Nekatere izmed fosilnih epifreatičnih jam imajo razvita tudi vadozna brezna, kar nakazuje na njihov prehod iz epifreatične v vadozno cono, kjer se sedaj nahajajo. Obstoj nekdanjih epifreatičnih jam dokazuje tudi najdba brezstrope jame na krednih apnencih na 
južnem pobočju pod Rigljem, približno $500 \mathrm{~m}$ od kontakta s fliši. V njej so bili najdeni do $3 \mathrm{~cm}$ veliki kosi peščenjaka. Zaradi znižanja kraškega površja je bil jami odstranjen strop in danes je vidna kot plitva uleknina na kraškem površju (Gostinčar, 2009).

Slika 2: Geomorfološka karta območja med Grintovcem, Rigljem in Starim Bregom. Fotografija prikazuje ponor v eni izmed slepih dolin v zahodnem delu preučevanega območja Figure 2: Geomorphological map of area between Grintovec, Rigelj and Stari Breg. Inset: a ponor in one of the blind valleys in the western part of case study area

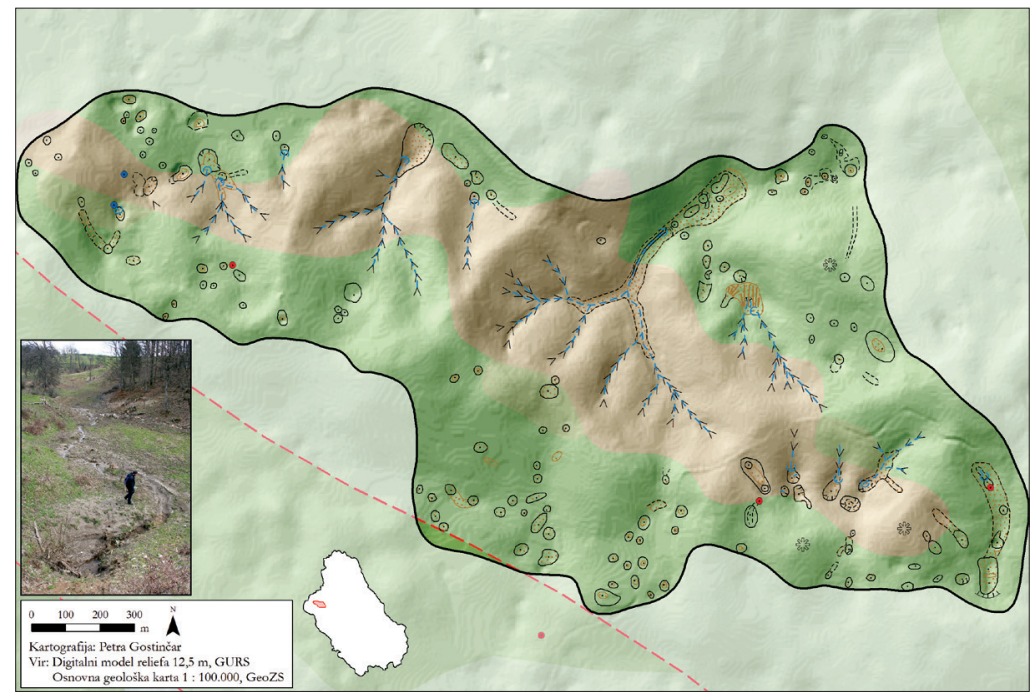

Slika 3: Legenda geomorfoloških kart

Figure 3: Legend of the geomorphological maps

\begin{tabular}{|c|c|c|}
\hline Geomorfologija & plitva kotanja & Litologija \\
\hline - jama & Drrtača & $\mathrm{E}_{1,2}$ \\
\hline - izvir & 然 kamnolom & $\mathrm{K}_{2}^{3}$ \\
\hline ens kopast vrh & vršaj $^{-}$ & $\mathrm{K}_{2}^{2}$ \\
\hline ------ blag pregib & debelejši sedimenti & $\mathrm{K}_{1,2}$ \\
\hline तााता oster pregib & $\square$ preučevano območje & $\mathrm{J}_{3}^{2,3}$ \\
\hline ヤヤ jarek (antropogeno) & & $\mathrm{J}_{3}^{2,3}$ (dolomit) \\
\hline erozijski jarek & Geološka struktura & $\mathrm{J}_{3}^{1,2}$ \\
\hline כ כ dolec & — prelom (ugotovljen) & $\mathrm{J}_{2}$ \\
\hline$\frown$ stalni vodotok & - - prelom (pokrit) & $\mathrm{J}_{1}$ \\
\hline -_občasni vodotok & - - - prelom (fotogeološko opazovan) & $\mathrm{P}_{1,2}$ \\
\hline$\frown$ ponor & - - čelo luske (pokrito) & \\
\hline$\sum \mathrm{kal}$ & $\perp \perp$ čelo nariva (pokrito) & \\
\hline
\end{tabular}




\subsection{Kontaktni kras na stiku različnih karbonatnih kamnin}

\subsection{Nemška Loka}

Nemška Loka je v dinarski smeri potekajoča, $1170 \mathrm{~m}$ dolga in do $310 \mathrm{~m}$ široka kraška kotanja v južnem delu Koprivniškega podolja na nadmorski višini 445-510 m, ki je bila opredeljena kot uvala (Habič in sod., 1990), oziroma kraško polje (Novak, 1968; Gostinčar, 2009). Kotanja ima izrazit strm rob le na dveh straneh - na zahodni strani jo omejuje greben Kočevske Male gore, na jugovzhodni pa hrib Vršič (686 m). Severno od Nemške Loke se Koprivniško podolje počasi dviguje proti severozahodu, na južni strani je z nižjim pretržjem ločeno od Poljanske doline (Gostinčar, 2009). Območje Nemške Loke je nastalo na stiku med jurskimi dolomiti in apnenci. Zahodno pobočje je iz spodnjejurskih liasnih dolomitov in dolomitiziranih apnencev $\left(\mathrm{J}_{1}\right)$ ter doggerskih apnencev $\left(\mathrm{J}_{2}\right)$. Severovzhodno pobočje gradijo spodnjemalmski apnenci in dolomiti $\left(\mathrm{J}_{3}^{1,2}\right)$, jugovzhodno območje pa zgornjemalmski apnenci $\left(\mathrm{J}_{3}^{2,3}\right)$. Kotanja je po vsej verjetnosti tektonskega nastanka, saj je nastala ob prelomu v dinarski smeri, nekaj prelomov poteka tudi v prečnodinarski smeri (Osnovna geološka karta SFRJ, list Črnomelj, 1983).

Zahodno in severozahodno pobočje, ki predstavlja glavno vodozbirno območje za vodotok, ki je nasul sedimente v Nemški Loki, je razčlenjeno z erozijskimi jarki, dolci ter vrtačami. Erozijski jarki so verjetno nastali v prelomni coni, kar dokazuje najdba dolomitnih kataklastičnih kamnin (prelomna breča). Nekateri erozijski jarki in dolci se zaključujejo že na pobočju, kjer se pod njimi nahajajo naplavine v obliki vršajev. Erozijski jarek, ki ima na severozahodnem pobočju največje zaledje, sega do ravninskega dela Nemške Loke. Vzhodno pobočje je razčlenjeno z vrtačami, ki pa jih ni veliko; pogosteje se pojavljajo tudi blage konkavne podolgovate oblike, za katere pa ne moremo trditi, da so dolci.

Dno kotanje je v celoti zasuto z naplavinami v obliki vršaja, ki so ga večinoma nasule vode iz erozijskih jarkov s strmega zahodnega pobočja. V sedimentu prevladujejo nezaobljeni dolomitni delci velikosti do $3 \mathrm{~cm}$, velikost delcev in debelina sedimenta pa upada od severozahoda proti jugovzhodu. Na jugovzhodu, kjer je dolomitni sediment delno odložen čez zgornjemalmske apnence, je površje nekoliko bolj razčlenjeno. Občasne, hudourniške vode se pretakajo po antropogeno preoblikovani strugi. Nizke vode poniknejo v sediment, še preden pridejo na uravnani del kotanje, ob visokih vodah pa se struga močno podaljša do manjšega ponora na jugovzhodu v bližini kontakta med dolomiti in apnenci. Ob ponoru se ni izoblikoval ponorni zatrep ali slepa dolina.

Jugovzhodni del Nemške Loke, kjer se pojavljajo zgornjemalmski apnenci, je bolj zakrasel kot dolomitna območja. Značilna je velika razčlenjenost površja z vrtačami in škrapljami (Gostinčar, 2009).

Na tem preučevanem območju, oziroma v njegovi bližnji okolici ni prisotnih jam z vodoravnimi odseki. 
Slika 4: Geomorfološka karta Nemške Loke. Fotografija prikazuje dno preučevanega območja, v ozadju so vidna pobočja, na katerih je prisotna površinska rečna mreža

Figure 4: Geomorphological map of Nemška Loka. Inset: the bottom of case study area; in the background the slopes with surface drainage network

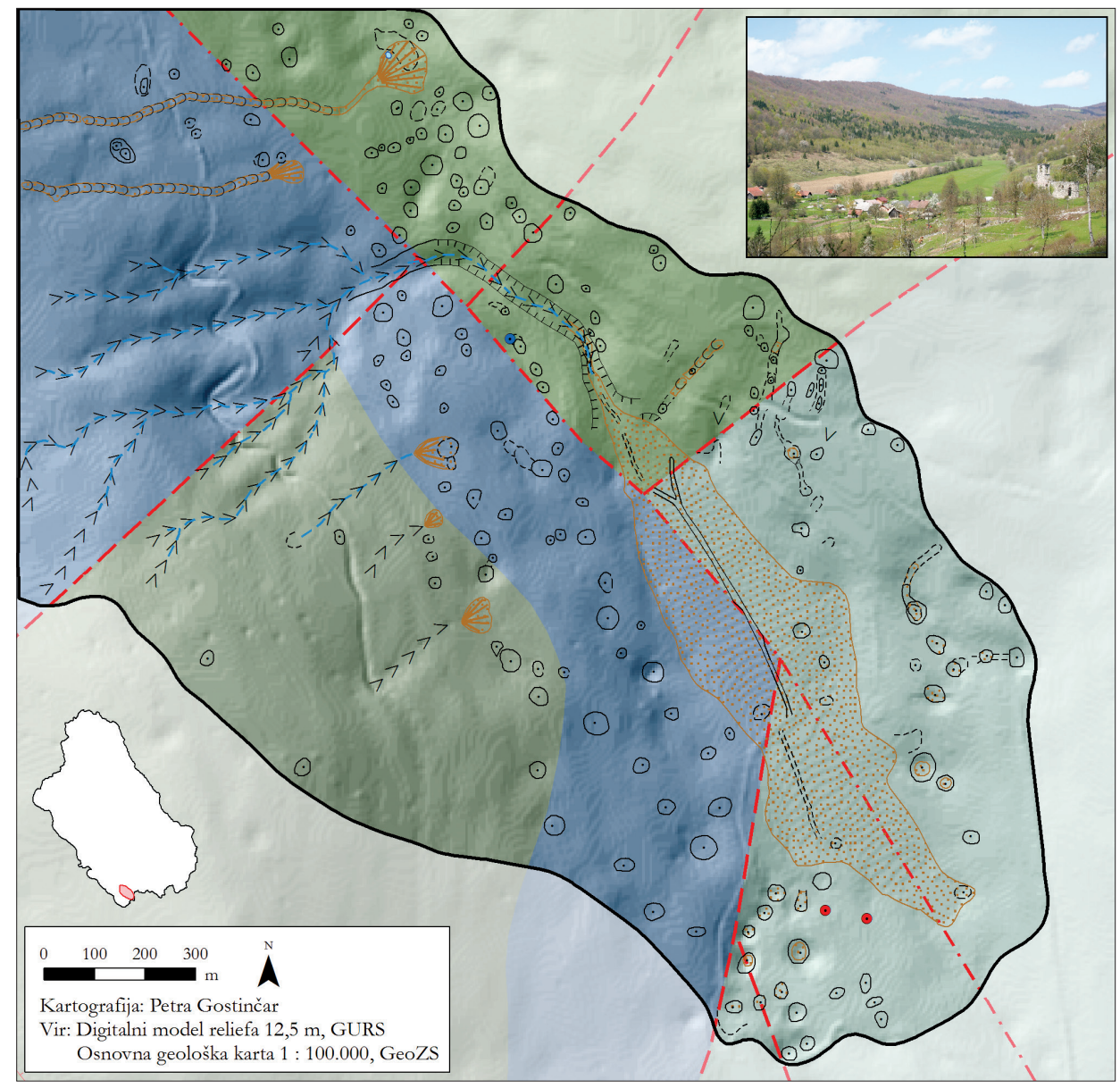

\subsubsection{Ribnik}

Ribnik je v smeri SZ-JV potekajoča, $1000 \mathrm{~m}$ dolga in do $260 \mathrm{~m}$ široka kraška kotanja v osrednjem delu Kočevskega Roga na nadmorski višini okoli 660 m (uvala - Habič in sod., 1990; kraško polje - Lehmann, 1933; Savnik, 1971). Ribnik je na zahodni in jugozahodni strani omejen s strmim robom, na severovzhodni, vzhodni in jugovzhodni strani meji na nekoliko višje zakraselo površje. Območje Ribnika se je izoblikovalo na stiku med dolomiti in apnenci. Skrajno jugozahodno pobočje gradijo dolomitizirani apnenci in dolomiti liasne starosti $\left(\mathrm{J}_{1}\right)$, osrednji del Ribnika je $\mathrm{v}$ 
zgornjemalmskih dolomitih $\left(\mathrm{J}_{3}^{2,3}\right)$, apnenci iz istega obdobja se pojavljajo na zahodnem in vzhodnem robu. Preko osrednjega dela Ribnika poteka prelom v dinarski smeri kotanja je usmerjena v osi preloma (Osnovna geološka karta SFRJ, list Črnomelj, 1983; Bukovac in sod., 1984).

Dno kotanje Ribnika je razčlenjeno na dve stopnji v nadmorskih višinah okoli $690 \mathrm{~m}$ in $660 \mathrm{~m}$. Morda gre za strukturno stopnjo ali pa je bil ta del dvignjen ob prelomni strukturi. Na severozahodni strani se na pobočju pojavlja konkavna oblika, zapolnjena s karbonatnimi sedimenti, ki se nadaljuje v niz vrtač, prav tako v dnu zapolnjene s karbonatnimi sedimenti. Dolomitna pobočja večinoma niso razčlenjena z vrtačami.

$\mathrm{Na}$ zahodnem robu Ribnika se nahaja pet erozijskih jarkov, dolgih od 100 do $350 \mathrm{~m}$, ki so se izoblikovali na dolomitni podlagi ob prelomni coni. Prelomno cono dokazujejo najdbe dolomitnih kataklastičnih kamnin. Ob izteku erozijskih jarkov v osrednji del Ribnika so se odložili sedimenti v obliki petih vršajev. Ti prekrivajo celotni zahodni del kotanje, dolžina vršajev znaša 150-220 m. Analiza vzorcev sedimentov je pokazala, da prevladujejo drobnozrnati in zaobljeni delci (nobeden ne presega dolžine $4 \mathrm{~mm}$ ), večinoma boksita. Debelina vršajev se manjša od zahoda proti vzhodu. S tanjšanjem debeline sedimentov se povečuje število kotanj oziroma vrtač ter njihova globina. Na litološkem stiku z mikritnimi apnenci je nastal oster prehod med s sedimenti uravnanim dnom ter bolj zakraselim vzhodnim pobočjem. Zahodni in jugozahodni del, ki je oblikovan na apnenenčasti matični podlagi, je močno zakrasel - pojavljajo se škraplje in vrtače, kamnitost površja pa je velika.

Voda teče danes površinsko po vsej verjetnosti le ob viških padavin, sicer ponikne v sedimentu, še preden doseže osrednji del kotanje. Na območju Ribnika so trije sufozijski grezi, ki kažejo na podtalno premikanje vodnih mas. Na stiku med apnenci in dolomiti so odloženi vršaji, morfološko izrazite slepe doline se niso izoblikovale. Morda so konkavne oblike na stiku med apnenci in dolomiti fosilni ponori, na kar lahko sklepamo po njihovi legi na robu vršajev, od koder je voda točkovno odtekala v kras.

$\mathrm{Na}$ tem preučevanem območju oziroma v njegovi bližnji okolici ni jam z vodoravnimi odseki. 
Slika 5: Geomorfološka karta Ribnika. Fotografija prikazuje dno kotanje, razčlenjeno z vršaji, ki so bili naneseni z zahodne (na fotografiji leve) strani

Figure 5: Geomorphological map of Ribnik. Inset: the bottom of the depression where the alluvial fans were deposited from the west (left on the photograph)

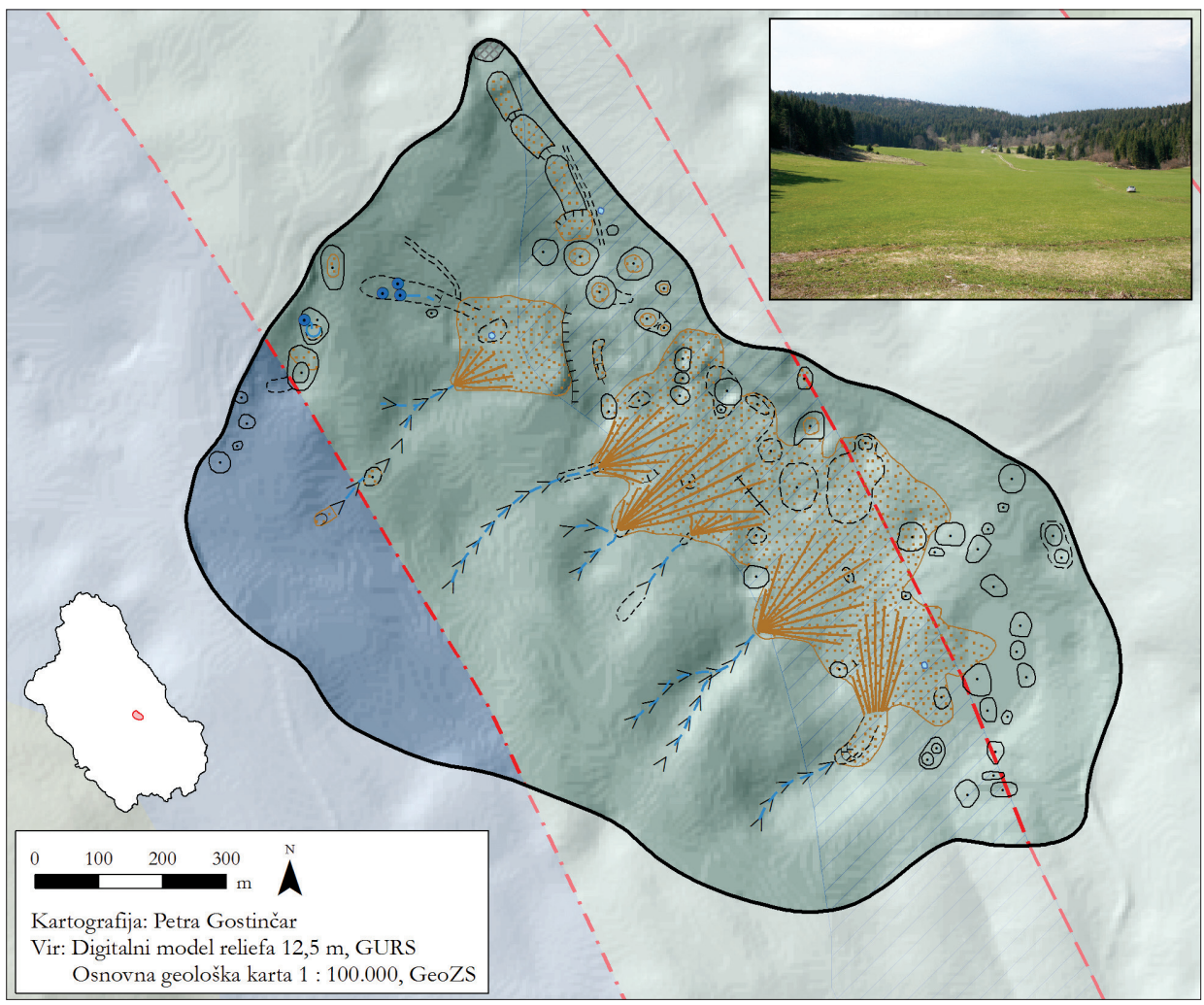

\subsubsection{Svetli Potok}

Svetli Potok leži na južni strani Kočevske Male gore in je porečje manjšega vodotoka, ki se je oblikovalo na kontaktu med apnenci in dolomiti. Območje zahodno od glavnega vodotoka ter njegovo zaledje predstavljajo spodnjemalmski apnenci in dolomiti $\left(\mathrm{J}_{3}^{1,2}\right)$, območje vzhodno od glavnega vodotoka pa gradijo dolomitizirani apnenci in dolomiti liasne starosti $\left(\mathrm{J}_{1}\right)$. Usmerjenost glavne struge je tektonsko pogojena, saj se v smeri sever-jug, kakor je usmerjen tudi glavni tok, pojavlja prelomna cona (Osnovna geološka karta SFRJ, list Črnomelj, 1983; Bukovac in sod., 1984).

Na severnem delu Svetlega Potoka so izoblikovani erozijski jarki in podolgovate konkavne oblike. V njihovih dneh se nahajajo naplavine, po katerih občasno teče voda. 
Slika 6: Geomorfološka karta Svetlega Potoka. Na fotografiji je prikazano površinsko pretakanje vode v enem izmed erozijskih jarkov na severovzhodnem delu preučevanega območja Figure 6: Geomorphological map of Svetli Potok. Inset: surface drainage in one of the erosion gullies in the northeastern part of the case study area

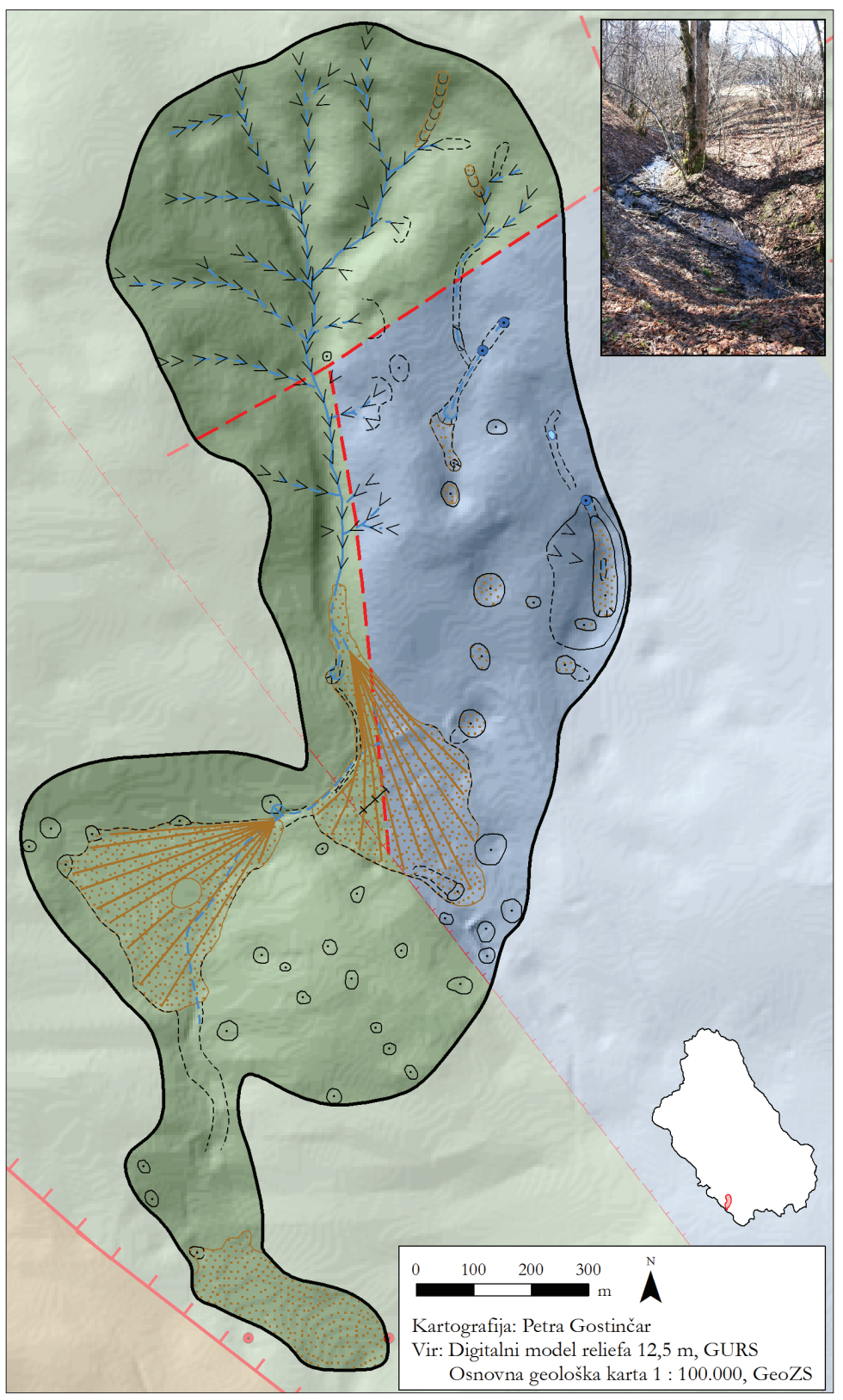


Za osrednji del območja so značilni erozijski jarki, po katerih voda odteka površinsko in se združuje v vodotok, ki nato po nekaj več kot kilometru toka v bližini nekdanje vasi Svetli Potok ponikne v nekaj metrov širokem ponornem zatrepu na kontaktu med dolomiti in apnenci. Vodotok je na stiku z apnencem izoblikoval fosilno slepo dolino na nadmorski višini $624 \mathrm{~m}$, ki v širino doseže $280 \mathrm{~m}$, v dolžino pa največ $450 \mathrm{~m}$. Ta slepa dolina ni tipična, saj nima sklenjenega ali strmega zatrepa. Na jugozahodnem robu ima opazen pregib na stiku $\mathrm{z}$ apnencem, $\mathrm{v}$ smeri proti jugu pa njen obod ni tako očiten in slepa dolina postopoma prehaja $v$ zakraselo površje. V slepi dolini so bili v obliki vršaja odloženi slabo zaobljeni dolomitni sedimenti. V smeri proti jugozahodu je vodotok v okoliških apnencih oblikoval še eno manj izrazito slepo dolino na nadmorski višini $612 \mathrm{~m}$, ki v širino meri največ $320 \mathrm{~m}$, v dolžino pa $380 \mathrm{~m}$ (Gostinčar, 2009), ponori na koncu slepe doline pa danes niso več vidni. Po Mihevcu (1991) je ta reliefna oblika suha dolina. V tej slepi, oziroma suhi dolini je v obliki vršaja odložen dolomitni sediment. Konec te slepe oziroma suhe doline se nadaljuje z ožjo suho dolino, usmerjeno proti jugu v smeri kotanje pri Studenem. V tej kotanji je deloma odložen dolomitni material, deloma se tja stekajo vode z južneje ležečih permskih nekarbonatnih kamnin (Mihevc, 1991; Gostinčar, 2009).

Na območju Studenega, kamor so se po danes fosilni suhi dolini stekale vode s Svetlega Potoka, se pojavljata dve jami z vodoravnimi oziroma epifreatičnimi odseki - Kavranova jama (kat. št. 4909) in Brlog na Rimskem (kat. št. 4209). Dostopni deli jam so ostanek spleta rovov, po katerih je proti severu odtekala voda ponikalnic iz Studenega, verjetno pa tudi voda Svetlega Potoka (Mihevc, 1991; Kataster jam JZS, 2010).

\section{SKLEP}

Na območju Kočevskega Roga in Kočevske Male gore so bila preučena štiri območja kontaktnega krasa, in sicer eno območje s kontaktnim krasom na stiku nekarbonatnih in karbonatnih kamnin ter tri območja s kontaktnim krasom na stiku različnih karbonatnih kamnin.

Na kontaktu med nekarbonatnimi (eocenskimi flišnimi) in karbonatnimi kamninami (kredni apnenci) na območju med Grintovcem, Rigljem in Starim Bregom so se razvile morfološko jasno izražene slepe doline, ponekod pa voda ponikne v ponikvi. V enem primeru je na površju prisotna tudi fosilna slepa dolina. Na kontaktu so ponekod prisotne podolgovate konkavne reliefne oblike, ki so v dnu zapolnjene z nekarbonatnimi sedimenti, danes pa po njih voda ne teče več. Vrtače v bližini kontakta so prav tako zapolnjene z nekarbonatnimi sedimenti. S kontaktnim krasom so povezane tudi značilnosti jam, ki imajo vodoravne epifreatične rove, vendar pa so jame danes od kontakta oddaljene in se nahajajo v vadozni coni. V bližini kontakta je bila identificirana tudi brezstropa jama, zapolnjena $\mathrm{z}$ nekarbonatnimi sedimenti.

Za razliko od kontaktnega krasa med nekarbonatnimi in karbonatnimi kamninami so na stiku med različnimi karbonatnimi kamninami - dolomiti in apnenci - reliefne oblike kontaktnega krasa nekoliko manj jasno izoblikovane. Fluvialno preoblikovanje reliefa je prisotno na območju notranjih delov prelomnih con (v porušeni coni po Čaru, 
1982). Pobočja so razčlenjena z erozijskimi jarki in dolci. Na koncih erozijskih jarkov in dolcev so odloženi sedimenti v obliki vršajev, vendar v dolcih ni opaziti aktivnega recentnega fluvialno-akumulacijskega preoblikovanja. Na kontaktu med dolomiti in apnenci so oblikovani ponori (Nemška Loka), fosilni ponori (Ribnik), ponorni zatrepi (Ribnik) ter suhe doline (Ribnik). Fluvialno nanešen sediment z dolomitnih pobočij ponekod prekriva litološki stik med dolomiti in apnenci. Kjer je matična podlaga sicer apnenec, vendar prekrit z dolomitno preperelino, je površje bolj vegasto, kar nakazuje na postopno zakrasevanje in spiranje sedimenta $\mathrm{v}$ kras. Jame $\mathrm{z}$ epifreatičnimi rovi so prisotne le na območju južno od Svetlega Potoka, vendar je njihov razvoj povezan tudi s stikom z nekarbonatnimi kamninami, ki se nahajajo južno od preučevanega območja. $\mathrm{Na}$ dveh preučevanih območjih (Nemška Loka, Ribnik) je izoblikovana kraška kotanja, ki jo nekateri avtorji uvrščajo med uvale ali robna kraška polja.

Primerjava obsega reliefnih oblik in sedimentov na obeh tipih kontaktnega krasa z intenzivnostjo današnjih geomorfnih procesov nakazuje, da so bili izoblikovani v drugačnih geomorfnih razmerah, ko so bili denudacijski ter erozijsko-akumulacijski procesi bolj intenzivni. Datacije na vzorčnih območjih še niso bile izvedene, zato ne moremo z gotovostjo trditi, kdaj so se odvijali omenjeni geomorfni procesi.

Ko je bilo v pleistocenu območje Kočevskega Roga in Kočevske Male gore pod vplivom periglacialnih geomorfnih procesov, so zaradi tvorjenja prepereline ter njene zamrznjenosti vode lahko odnašale dolomitni drobir tudi na sosednja apnenčasta območja. Fluvialni transport je potekal po erozijskih jarkih in verjetno tudi tam, kjer so danes v reliefu izoblikovani dolci. Posledica intenzivnega zmrzalnega preperevanja ter intenzivne denudacije in soliflukcije je lahko bilo tudi obilno nasipanje gradiva v nižje lege, s čimer bi lahko pojasnili sedimente v obliki vršajev, ki se nahajajo pod dolci (Komac, 2006). $\mathrm{Na}$ območjih nekarbonatnih kamnin (eocenske flišne kamnine) pa ostanki nekdanjega reliefa ter sedimenti na površju in v jamah nakazujejo, da je bil nekdaj obseg nekarbonatnih kamnin večji, današnje območje teh kamnin pa predstavlja njihov erozijski ostanek (Germovšek, 1953; Gostinčar, 2009).

Poleg prispevka k poznavanju reliefa na območju Kočevskega Roga in Kočevske Male gore je pomembna ugotovitev, da na tovrstnih območjih obstaja tudi kontaktni kras med različnimi karbonatnimi kamninami, oziroma med apnenci in dolomiti. Raziskava je pokazala, da obstaja potreba po sistematični preučitvi tega tipa kontaktnega krasa, saj se apnenci in dolomiti v Sloveniji ponekod menjavajo na zelo kratke razdalje, skupaj pa obsegajo več kot 40 \% površja Slovenije (Gams, 2003).

\section{Viri in literatura}

Bukovac, J., Poljak, M., Šušnjar, M., Čakalo, M., 1984. Osnovna geološka karta SFRJ. Tumač za list Črnomelj. Beograd, Zvezni geološki zavod, 59 str.

Čar, J., 1982. Geološka zgradba požiralnega obrobja Planinskega polja. Acta carsologica, 10, str. 75-105. Ljubljana.

Čar, J., Šebela, A., 2001. Kraške značilnosti narivnega stika apnenec - dolomit pri Predjami. Acta carsologica, 30, 2, str. 141-156. Ljubljana. 
Čar, J., Zagoda, B., 2005. Strukturna lega Habečkovega brezna. Acta carsologica, 34, 1, str. 113-133. Ljubljana.

Ford, D., Williams, P., 2007. Karst hydrogeology and geomorphology. Chichester, John Wiley \& Sons, 562 str.

Gams, I., 1962. Slepe doline v Sloveniji. Geografski zbornik, 7, str. 263-306. Ljubljana.

Gams, I., 1974. Kras: zgodovinski, naravoslovni in geografski oris. Ljubljana, Slovenska matica, 358 str.

Gams, I., 1983. Škocjanski kras kot vzorec kontaktnega krasa. V: Mednarodni simpozij »Zaščita Krasa ob 160-letnici turističnega razvoja Škocjanskih jam«, Lipica, 7.-9. oktobra 1982, str. 22-26. Sežana.

Gams, I., 1986. Kontaktni fluviokras. Acta carsologica, 14/15, str. 71-87. Ljubljana.

Gams, I., 1995. Types of contact karst. Studia carsologica, 6, str. 98-116. Brno.

Gams, I., 2001. Notion and forms of contact karst. Acta carsologica, 30, 2, str. 33-46. Ljubljana.

Gams, I., 2003. Kras v Sloveniji v prostoru in času. Ljubljana, Založba ZRC, 516 str.

Germovšek, C., 1953. Zgornjekredni klastični sedimenti na Kočevskem in v bližnji okolici. Geologija, 1, str. 120-134. Ljubljana.

Gostinčar, P., 2009. Geomorfološke značilnosti Kočevskega Roga in Kočevske Male gore. Diplomsko delo. Ljubljana, Filozofska fakulteta, Oddelek za geografijo, 154 str.

Habič, P., 1968. Kraški svet med Idrijco in Vipavo: prispevek k poznavanju razvoja kraškega reliefa. Ljubljana, Slovenska akademija znanosti in umetnosti, $243 \mathrm{str}$.

Habič, P., 1989. Sledenje kraških voda v Sloveniji. Geografski vestnik, 61, str. 3-20. Ljubljana.

Habič, P., Kogovšek, J., Bricelj, M., Zupan, M., 1990. Izviri Dobličice in njihovo širše kraško zaledje. Acta carsologica, 19, str. 5-100. Ljubljana.

Hribernik, M., 2005. Kontaktni kras v zahodnem delu Ložniškega gričevja. Diplomsko delo. Ljubljana, Filozofska fakulteta, Oddelek za geografijo, 136 str.

Hrvatin, M., 1999. Mala gora, Kočevski rog in Poljanska gora. V: Slovenija: pokrajine in ljudje. Ljubljana, Mladinska knjiga, str. 436-446.

Kataster jam Jamarske zveze Slovenije (stanje na dan 31. 12. 2010).

Komac, B., 2006. Dolec kot značilna oblika dolomitnega površja. Ljubljana, Založba ZRC, 171 str.

Lapanje, A., 2000. Hidrogeologija dolomitnega vodonosnika Mirne gore na severozahodu Bele krajine. Magistrsko delo. Ljubljana, Naravoslovnotehniška fakulteta, Oddelek za geologijo, 138 str.

Lehmann, E., 1933. Das Gottscheer Hochland: Grundlinien einer Landeskunde. Leipzig, Museum für Länderkunde zu Leipzig, 67 str.

Melik, A., 1955. Kraška polja Slovenije v pleistocenu. Ljubljana, Slovenska akademija znanosti in umetnosti, 162 str.

Mihevc, A., 1979. Geomorfološka karta ozemlja Logaških Rovt. Diplomsko delo. Ljubljana, Filozofska fakulteta, Oddelek za geografijo, 63 str..

Mihevc, A., 1989. Kontaktni kras pri Kačičah in ponor Mejame. Acta carsologica, 18, str. 173-195. Ljubljana. 
Mihevc, A., 1991. Morfološke značilnosti ponornega kontaktnega krasa: izbrani primeri s slovenskega krasa. Magistrsko delo. Ljubljana, Filozofska fakulteta, Oddelek za geografijo, 206 str.

Mihevc, A., 1993. Contact karst of Brkini Hills. V: Proceedings of 1st International Karstological School »Classical Karst«, Lipica, September 20-23, 1993, str. 5-7. Postojna.

Mivšek, T., 2007. Geomorfologija ozemlja med Črnim Vrhom in Medvedjim Brdom. Diplomsko delo. Ljubljana, Filozofska fakulteta, Oddelek za geografijo, 88 str.

Novak, D., 1968. Ponikve na Kočevskem Rogu. Naše jame, 10, str. 89-91. Ljubljana.

Osnovna geološka karta SFRJ. List Ribnica. 1968. 1:100.000. Beograd. Zvezni geološki zavod.

Osnovna geološka karta SFRJ. List Delnice. 1984. 1:100.000. Beograd. Zvezni geološki zavod.

Osnovna geološka karta SFRJ. List Črnomelj. 1983. 1:100.000. Beograd. Zvezni geološki zavod.

Premru, U., Ogorelec, B., Šribar, L., 1977. O geološki zgradbi Dolenjske. Geologija, 20, str. 167-192. Ljubljana.

Radinja, D., 1972. Zakrasevanje v Sloveniji v luči celotnega morfogenetskega razvoja. Geografski zbornik, 13, str. 197-243. Ljubljana.

Renault, P., 1967. Contribution à l'étude des actions mécaniques et sédimentologiques dans la spéléogenese. Annales de Spéléologie, 22, 1, str. 5-21 in 22, 2, str. 209-307.

Sauro, U., 2001. Aspects of contact karst in the Venetian Fore-Alps. Acta carsologica, 30, 2, str. 89-102. Ljubljana.

Savnik, R. (ur.), 1971. Krajevni leksikon Slovenije. Knj. 2. Jedro osrednje Slovenije in njen jugovzhodni del. Ljubljana, Državna založba Slovenije, 705 str.

Stepišnik, U., 2006. Udornice na slovenskem krasu. Doktorska disertacija. Ljubljana, Filozofska fakulteta, Oddelek za geografijo, 192 str.

Stepišnik, U., Ferk, M., Gostinčar, P., Černuta, L., Peternelj, K., Štembergar, T., Ilič, U., 2007a. Alluvial fans on contact karst: an example from Matarsko podolje, Slovenia. Acta carsologica, 36, 2, str. 209-215. Ljubljana.

Stepišnik, U., Černuta, L., Ferk, M., Gostinčar, P., 2007b. Reliktni vršaji kontaktnega krasa severozahodnega dela Matarskega podolja. Dela, 28, str. 29-42. Ljubljana.

Sweeting, M. M., 1972. Karst landforms. London, Macmillan, 362 str.

Zagoda, B., 2004. Zakrasevanje ob narivnem stiku dolomita in apnenca v Idrijskem logu in Koševniku. Diplomsko delo. Ljubljana, Naravoslovnotehniška fakulteta, Oddelek za geologijo, 67 str. 


\section{CONTACT KARST OF KOČEVSKI ROG AND KOČEVSKA MALA GORA}

\section{Summary}

Kočevski Rog and Kočevska Mala gora are high Dinaric karst plateaus situated in southeastern part of Slovenia (Figure 1). From a geomorphological point of view, the karst geomorphic system is predominant but on some smaller areas the fluvial geomorphic system is also present. On the contact between the two systems, the so-called contact karst is present. The article focuses on geomorphological characteristics of four contact karst areas.

From a geological point of view, Kočevski Rog and Kočevska Mala gora, with an area of about 363 sq. km, are mostly composed of Mesozoic carbonate rocks - limestone and dolomite of Triassic, Jurassic and Cretaceous age. In a much smaller scale, Tertiary (Eocene non-carbonate rocks) and Quaternary sediments are present. The area is modified with tectonic structures of Dinaric and cross-Dinaric direction (Hrvatin, 1999).

Contact karst is a type of karst which is formed where allogenic waters from fluvial geomorphic system flow on the karst geomorphic system (Mihevc, 1991), i.e. the contact of impermeable and permeable (karstic) rocks (Gams, 1973; 2003). In a strict sense, we consider the contact karst as karst phenomenon and forms influenced by the contact between karstifiable and a non-karstifiable rocks. In a wider sense, the karst phenomena and forms influenced by the contact between two karstifiable rocks, different in some characters, may also be perceived as contact karst (Sauro, 2001). The first type of contact karst has been studied by many authors (Šerko, 1964; Čadež, 1952; Habič, 1975; 1988; Gams, 1962; 1983; 1986; 1995; 2001; Mihevc, 1989; 1991; 1993; Hribernik, 2005; Stepišnik et al., 2007a; 2007b; Stepišnik, 2009; 2010) while the latter has not been studied in detail yet - except for some small-scale investigations (Habič, 1968; Radinja, 1972; Mihevc, 1979; 1991; Čar, Šebela, 2001; Zagoda, 2004; Čar, Zagoda, 2005; Gams, 2003; Mivšek, 2007). Surface landforms, typical for contact karst are blind valleys, ponor steepheads (Mihevc, 1991), dry valleys, karst plains (Gams, 2001), groups of collapse dolines close to ponors of a major sinking stream (Stepišnik, 2006), border poljes (Gams, 2003) and relict alluvial fans (Stepišnik et al., 2007a).

In Kočevski Rog and Kočevska Mala gora, two types of contact karst were recognized: contact karst between non-carbonate and carbonate rocks, and between different carbonate rocks. Four case study areas were geomorphologically mapped in scales $1: 5,000$ or $1: 10,000$. To determine the source of rock and sediment samples, they were petrologically analyzed and some caves near the case study areas were investigated, too.

In the area between Grintovec, Rigelj and Stari Breg, there is about one sq. km large segment of impermeable Eocene flysch sediments on which fluvial relief was formed. Surface water flows in erosion gullies and typical contact-karst features on the contact between flysch and limestone appear: ponors and blind valleys (Figure 2). Some caves 
in the surrounding area (Ostra jama, No. 5111; Medvedova jama, No. 5112; Jama pri Jelenovi mlaki, No. 5117; Adidas jama, No. 6242; Kropfova jama, No. 7034; Prehodna jama, No. 3326; Kataster jam JZS, 2010) were filled with non-carbonate material and paragenetic horizontal passages were formed. Some relict fluvial landforms are also present. Non-carbonate sediments were also found in dolines, caves and unroofed caves in carbonate rocks that are away from today's contact karst.

The karst depression of Nemška Loka (uvala - Habič et al., 1990; polje - Novak, 1968; Gostinčar, 2009) is about $1170 \mathrm{~m}$ long and up to $310 \mathrm{~m}$ wide. It was formed on the contact between Jurassic dolomite and limestone and therefore the contact karst between the two rocks is present. The contact karst was also influenced by the fault that passes the depression. In the western part, which consist of dolomite, erosion gullies and surface water streams, dells and dolines are present. The central part is leveled due to fluvial deposits (alluvial fan) from the western part. The fluvial geomorphological processes are still active. On the contact with limestone, a smaller ponor was formed but neither ponor steephead nor a blind valley was formed (Figure 4).

The karst depression Ribnik (uvala - Habič et al., 1990; polje - Lehmann, 1933; Savnik, 1971; Gostinčar, 2009) is about $1000 \mathrm{~m}$ long and up to $260 \mathrm{~m}$ wide and like Nemška Loka it was also formed on the contact between Jurassic dolomite and limestone, in addition it was also influenced by a fault. On dolomite, erosion gullies are present. Below these gullies, on the contact with limestone, alluvial fans were deposited. The thickness of the sediment decreases towards east where gradual transition to karst surface features such as dolines is present. Some dolines near the contact could have been ponors at some time. No blind valleys were formed (Figure 5).

At Svetli Potok, the fluvial relief (length of about $1500 \mathrm{~m}$ ) is formed on Jurassic dolomite and on the contact with Jurassic limestone, contact karst was formed. In the northern part, erosion gullies and surface water streams are still active. On the contact between dolomite and limestone, a ponor with a ponor steephead is present. Further to the south, two fossil blind valleys and a dry valley are visible. The blind valleys are filled with fluvial sediments (Figure 6).

The research has shown that the surface features of contact karst between non-carbonate and carbonate rocks and between different carbonate rocks are similar but the latter are less evident. Instead of blind valleys, only ponors (active or fossil), ponor steepheads, and dry valleys are formed. A common surface feature on the contact karst between different carbonate rocks are also alluvial fans, what isn't the case in carbonate - non-carbonate contact karst. On the contact between different carbonate rocks the caves are also absent. 